\title{
The Concept of Morality in Education Discourse
}

\author{
M. A. Ayeni \\ Department of Educational Foundations and Management, \\ Faculty of Education, University of Ado-Ekiti, Ado-Ekiti, Nigeria
}

\begin{abstract}
Morality in the realm of philosophy connotes habits or customs, it is the character of being in accord with the principles or standards of right conduct. This makes morality and education to be related. But there is an opinion that moral education is not a central concern of formal education, this opinion may be logically valid but educationally it looks unacceptable. However, the education premise of the statement looks faulty because nearly all the objectives and enterprises of formal education are directly and indirectly related to the moral sphere, therefore, it looks absurd to separate morality from education. The acceptable consensus that morality is subsumed in the definitions of education is a clear indication that morality and education are logically related. This conceptual paper attempts to explicate the interrelatedness between morality and education and how the two can work harmoniously for the survival of the societies in the world.
\end{abstract}

\section{Introduction}

It is not enough to know the good, one must equally be committed to it. One must not only know, one must also have the conviction that a particular course of action is the right one to take. For education of any kind to be more than a system of instruction, one must make a total response with the whole personality. It must entail comprehension and commitment. If either is lacking, then, the process becomes incomplete.

The term 'morals' however implies behaviour and the adjectives 'moral' and 'immoral' suggest behaviour which is acceptable and unacceptable. There is also a suggestion of 'social criteria', because when we talk about moral behaviour being acceptable and immoral behaviour being unacceptable, we think of the acceptance, or nonacceptance, by the society. Society has established norms or standards against which to measure different modes of behaviour to determine their acceptability or otherwise. And because norms or standards are established by society, there is a link between value-judgment, values and morals. All these are mutually related to education.

When society establishes its norms of good and bad behaviour, it is making a value-judgment. It is saying that some forms of behaviour are more socially acceptable, more in the interest of the majority than others. It makes these judgments not arbitrarily or in isolation, but in relation to the values which it holds. One may say that moral education is therefore only adequate if it both prepares learners to reach their own moral decision on the basis of valid criteria and also enables them to implement such decision. This apparently ensures that moral education results in actual moral conduct and so does not merely produce an ethically bankrupt learner. Thus morality is seen as the ultimate aim of education. This however explains the paradox of morality in educational discourse.

But whatever argument that is made about morals and morality, people still arrive at the same idea that morality, morals and moral codes are all concerned with one primary object, namely the establishment of the good life. Good life here may be considered to mean 'comfortable life' as distinct from the 'necessary life'. The connection between morality and education is an important one. Through education, people understand the difference between right and wrong, between good conduct and bad conduct. Thus since moral and education are connected, children are made to reconcile the demands made by the general code of behaviour established by society and the sub-codes accepted by the smaller units within the society. This makes an explicit examination of morality and its relationship with education imperative.

\section{Background to Morality}

Moral situation is the sine-qua-non to moral education. In the consideration of morality, it is necessary to trace its foundation to all social science subjects. These subjects are evaluative and normative discipline, and of course philosophy through which concepts of morality are explicitly examined. Equally, next to philosophy in importance in the discussion of moral development is the psychology, what deals with the stages of moral development in the individual starting from childhood to adulthood. Equally important is the sociological perspective which concerns itself with the existence of morality as a social phenomenon, and its role in the achievement of peace and harmony in the society, as well as with the perception of morality through the process of 
socialisation of which it is universally believed that school is a veritable agency.

Although, religion as it will be discussed later in this paper has a traditional base in morality, it is observed that the two are complementary to each other. In the realm of economics, morality is evident in the process of distributing scarce resources to meet unlimited demands. How this could be implemented without social unrest is another question. In the political realm, even when politics is said to be concerned with the sharing and wielding of power, moral questions cannot but be raised. Moral issues arise from the kind of relationship that exists between the ruler and the ruled, the oppressor and the oppressed, the proletariat and the capitalists, the employers and employees. Thus politics raises a lot of moral issues that are connected with the survival and harmonious existence of persons in the society.

Piaget is of the opinion that the bedrock of moral situation vis-à-vis morality is philosophy [10]. He believes that morality and philosophy are indispensable. Philosophy actually arrogates to itself the self-appointed duty of analysing the words and concepts that are used, offering and criticising various definitions used, placing the concepts within the context of system-concepts, so as to detect the differences and similarities as well as the nuances and generally constructing broad parameters of correct usage. It cannot be over-emphasised that this is a most distinguished contribution that philosophy makes to a happy and harmonious living, because it is true that if two people in some social relationship cannot even agree on the way they are to use words, the possibility of a better alternative is the existing code. One may be tempted to question the morality of the so-called moral code. The simple reason is that morality is not an empirical 'fact' which is verifiable in the way that scientific data are verifiable and agreed upon. Morality whether in terms of moral conduct or in terms of moral discourse involves human judgment, a value judgment between two or more alternatives, between right and wrong and the various shades that lie between both extremes.

\section{Philosophical Conception of Morality}

Philosophers' major occupation is the examination of what is meant by the term moral or rather the real meaning of morality. What makes an action or behaviour moral and proper or rather immoral and improper? For example, if a student sees money on the playing field and picked it up, the mere picking it up may be moral or immoral, it depends on what follows. If he eventually gives the money to the teacher for announcement, then the action is moral, but if he decides to spend the money on his own, the action may be seen as immoral. Just as we can contrast moral with immoral so also we can make a distinction between moral and nonmoral. Knocking the head of a friend in a wrestling competition is non-moral but knocking the head of a friend during simple disagreement that could be resolved amicably is immoral.

In line with Akinpelu's opinion, any meaningful discourse on morals must therefore start with the analysis of concepts which are peculiar to morals, and which recur again and again in subsequent moral discourse [1]. Among such moral concepts are the notions or ideas of 'right' and 'wrong', 'good' and 'bad', 'approved' and 'disapproved', 'praise-worthy' and 'blame-worthy', 'ought' and 'ought not', 'virtue' and 'vice', 'desirable' and 'undesirable', 'acceptable' and 'unacceptable'. They are words which we express our judgments or characterise human actions, conducts and behaviours. Much of the writings on moral philosophy have been on the explication and clarification of these concepts particularly with delineating the criteria that work out the one from the other. Another area of philosophical concern is the process of compatibility between moral situation and moral education. This, however, is the process of inducting the young into the culture and life of morality. As a matter of fact, one needs to know that moral instruction, moral training and moral education has subtle distinctions between them. But moral education seems to be more comprehensive and acceptable because of its broadness and its all encompassing nature unlike the other two that connote narrowness and restriction in the content and process.

Peters affirmed that children must first be habituated to what is moral, right and good before they can fully reason about these issues to arrive at their own decisions [9]. Children, he says, can and must enter the palace of reason through the courtyard of habit and tradition. Can someone claim that students have been morally educated once they have been able to answer correctly examination questions on the unit of moral education taught to them? Or do we have to watch them in their subsequent actions, conducts or behaviours before we can conclude that the unit has been successfully taught to them? What constitutes 'success' in moral education? These highlight philosophical questions that only analysis and thorough examination of some principles can answer.

Schofield opined that morality is a social phenomenon whose aim is to secure a smooth and harmonious social relationship among human beings through fair and just consideration of the interest of all in the relationship [12]. Morality, according to McConnell, may be based on some social or cultural norms of a group of people, but such a moral code, even when hallowed by passage of time and made traditional, can still be subjected to question as to whether the particular moral code is really moral [8]. In some traditional African societies, it was permissible to entertain your male friend with your 
beloved wife. One can query the rationality or morality of such a practice even though the society practicing it might not see anything odd or amiss in it, not to mention immoral. Hence, the search for national morality which is based on canons of reason and justified by appeals to reason. It is on the basis of this that any discussion on morality can have any root in the mind of the students especially the adolescents.

Immanuel Kant was of the opinion that for people to be moral, effort must be made to treat humanity in every case as an end never as a means only, for to treat people as an end is to treat their persons with respect and to consider their interest [4]. If people are to be treated as a means to an end, then they may be regarded as a living tool. What all these mean for the school management is the need to balance both types of interests that are necessarily involved, and harmonise them for the maximum benefit of both parties. While trying to maintain discipline and order in the interest of the whole school, it must not be forgotten that the interest of the smallest kid in the school should also be considered. Again, the tendency to present rules and regulations as absolute and unchangeable codes is wrong and may result in undermining the fraction and personality development of those subjected to them. It should be possible to make students accept those codes on the basis of their understanding and appreciation of the need for such codes, and the fairness of the codes to all interests considered.

Kohlberg asserts that any act that is marked as moral must be in the interest of individual and the generality of the people [7]. The act must however pay respect to the humanity of the person who is to be at the receiving end, his freedom and autonomy. He must be treated, in the words of Immanuel Kant, as 'an end-in-himself and not only as a means to an end.'

To be described as moral, an act must be tested under the golden rule, that is, do unto others as you would like them to do unto you. And when someone acts in a particular way he does so under a principle and he is implicitly prescribing that all other people in circumstances similar to that should do the same. Hence, if it is a principle which one is not ready to prescribe for others or to universalise, that principle must be held suspect and the act regarded as immoral or classified as 'messy morality' as described by Coady [3]. What one has to do is to support what he teaches or preaches with evidence which people can accept because it is rational. Rational evidence through the eyes of philosophy is free from bias, personal preference and prejudice.

\section{Religious Conception of Morality}

Some people believe that there is a great relationship between religious education and moral education. Others say there is none, for each has different aims. The more sophisticated plead for a total severance, arguing that when a child's morality is supported by religious notions, it will collapse if religion is rejected in puberty. On the other hand, some say that many objectives of religious and moral education coincide, for although religion and morality each make distinct contributions to human life. There is a large area of overlap. Even a brief perusal of modern religious education syllabuses makes this clear. Such contention, they say, is supported by studies which reveal a correlation between religions and moral behaviour, by the persistence with which the two are constantly synthesised and by the ease with which religious morality can be accommodated to the ethos of a secular society, without shedding any of its essentials.

It is possible to argue that morality requires religious motivation. This is a positive approach to motivation and one which says that many people are good only for religious reasons, because they wish to obtain salvation. Again, there may be an element of negative religious motivation in some people's moral behaviour. They may fear that failure to live the good life will result in damnation, which of course, they wish to avoid. However, one cannot argue from this that all people live the good life only for religious reasons. We can find people like Tai Solarin of Nigeria who were motivated to live the good life and did the right because he believed, not in a supernatural Being, but in such concepts as peace, and social justice.

\section{Morality and the School System}

Although people frequently debate whether morality can be taught without teaching religion, there are few who would deny that morality without teaching religion, there are few who would deny that morality should be taught in school. Society generally agrees that morality not only can but 'ought' to be taught. It also accepts that the teacher is the one best qualified for the task.

Keninston raised the fear that the family and the adult society have abandoned their duties to morally educate, so also teachers in schools are becoming indifferent to the moral education of the children in their charge [6]. In schools, there is little or no specific moral education or moral instruction existing as examinable curriculum unit. Where moral education is said to exist, the subject usually referred to is religious education. Moral education in its real sense is undoubtedly lacking in most of our primary and secondary schools in Nigeria, the extension of which is noticeable in tertiary institutions. To tackle the problems that emanates from the above, a lot needs to be done. Firstly, the concept of morality must be properly understood as a form of arrangement between individuals in social situations which gives adequate considerations to the interests 
of others. In other words, rational or reason-based morality must be preferred to religious or traditional morality. The reason-based ethics make students see the whole point to morality, why they must be moral and how they can develop and progress morally. Such a morality while admitting of sanctions plays down the role of fear and threats in obtaining compliance, instead it appeals to their reason and enables them adjust their behaviours or attitudes. To enhance this type of reason-based moral education, school managers must thoroughly understand the foundations of morality, especially, the philosophical foundation which is fundamental to all the other foundations. Through this, they will be exposed to the conditions that must be satisfied before an act is described as moral. The psychological foundation is also very important for effective delivery of moral education since this will provide stages of moral development and understanding of the children, and at what stages to introduce different topics and different teaching methods according to the state of their psychological readiness.

Secondly at the early stages of a child's moral education, there should be preponderance of learning specific moral rules and principles without sophisticated justification, at the early stage the starting point should be the inculcation of rules of ethics, courtesies, civility and good manners. As a matter of fact, a child who has been accustomed to taking into consideration the feelings of others in his environment, would more easily develop into a morally mature adult. As his reasoning ability develops and matures, the rational method will take on greater emphasis until, all that would be taught will be procedural rules for making moral judgment.

Thirdly, schools must assume greater roles in moral education of students because of the failure of the homes, the religious bodies and adult world to be true moral educators. Teachers must apply themselves more zealously to the moral education of their students, schools must offer greater opportunities for effective reason-based moral education, through the development of the moral sensitivity of students and their capacity to make moral decisions. These theoretical learnings must be complemented by a proliferation of philanthropic and humanitarian projects by which students can display in action some of the moral principles and procedures learnt in classroom situations. The role of the teacher is most influential, and courtesy demands that they be first morally sensitised and educated before transferring it to their students. In actual fact, while teachers cannot carry the whole blame for the moral laxity among their students, they cannot at the same time pretend to be innocent.

The teacher in the area of morals is an interpreter. The philosopher is able to describe different types of life. The teacher must determine, in terms of the society in which he teaches and in terms of the experience of his pupils, which type of life it is best for them to lead. This is one example of the teacher having to consider the needs of the child in conjunction with the needs of society, and the demands developing out of them. The teacher has to deal at the practical level with material which the philosopher considers at the theoretical level. As said, in the introductory section the ultimate aim of the teacher is to bring his pupils to understand the difference between just and unjust, fair and unfair, good and bad conduct. It is argued that morality is inseparable from religion. If morality can be totally separated from religion well and good. It matters little whether religion is taught in schools or not, since the school can still discharge its social responsibility of teaching morality. However, if morality cannot be totally separated from religion, there are very clearly definable consequences for both teachers and pupils in the school system.

\section{The Preconditions of Morality}

These, it will be remembered, are primarily the establishment of one's identity, the acceptance of our ambivalent nature, and the paradigmatic experiences which result from access to ideal figures. These clearly constitute three primary aims in religious education. Children are given a stable identity in the myth-form of God, the father, they are thereby raised to the status of members of the human family. Consequently, it is natural to observe that one keynote of Christianity is the theological affirmation that all are accepted by Christ in spite of their inadequacies. Sociologists and philosophers however, have recently pointed to the overwhelming paradigmatic power of the person of Christ. He has now invaded the pop-culture and is enjoying an unexpected popularity amongst most sub-cultures through the medium of music. For children, the point is simple, they sing, for it is their childhood pattern and that is precisely the role of a paradigm in the process of identification.

As a matter of fact, when God gave the commandments to men, He gave preconditions as a set of rules infinitely more wise than any which men could devise by applying his own finite wisdom. Because these infinite wise rules came from God, we have the right to impose them on men. They are in the best interests of all. Man-made moral rules can be based only on personal preferences, preconditions, prejudices, faults, to which every keen intellect are prone.

\section{Moral Traits}

Moral personalism is so central to Christian teaching that any reference is superfluous. It has for two millennia sustained and advocated a lifestyle in which people, their feelings, well-being and future welfare are all deemed to take precedence over every other consideration. The moral flexibility inherent in 
Christian teaching has recently been made explicit by the new theology. It is now argued, for example, that the whole tenor of Christian ethical discourse resolves itself down to the proposition that legalism has been superseded by the enunciation of moral principles. Consequently, the New Testament makes it clear that every Christian should seek to elucidate those principles which had hitherto expressed through the medium of law.

The dynamism of this ideology however is apparent in the teaching of Jesus Christ. It is now generally accepted when Jesus taught in parables and ended each by saying 'Go ye and do likewise', he was not, for example, advocating that we should pour oil and wine into the wounds of travellers, give all our money to the poor, or go out and look for a lost sheep. He was saying in the parable how the principle of love would operate under those particular circumstances. Now go away and apply these principles in your own lives.

As a matter of fact, every human being is connected genetically with his parents and ancestors since he is composed of the same genes. He has the same physical nature or belongs to the same type. The analogy holds good for the concepts of religion and morality. They both involve ethics, that is, both are concerned with ideas about what is good and evil behaviour. They are therefore made of the same stuff, and are genetically connected.

\section{Moral Dispositions}

Autonomy, rationality, altruism and responsibility are equally central affirmation of Christian religious education. That Christ called men to exercise moral autonomy is now clear. He rejected the view that we should subscribe blindly to the law and insisted that His followers should go out to accept moral and religious principles which they then applied as free agents, without reference to any legal formula. That altruism is central to Christian teaching requires no explanation. Christianity is built upon the principle that love is a prime moral virtue. Nothing transcends it, and this transcendental form expresses the nature of ultimate reality, for 'God is love'. It is therefore incumbent upon all men to express this quality in their relationship.

However, Christians also believe that the cosmic principle of coherence and order, the logos, became incarnate in Christ. On this basis, the early Christians stressed that 'faith' should be coherently comprehended and cogently expressed in comprehensive terms. They assumed that just as words indicated the nature and meaning of mind, so the logos (or word) were a revelation of ultimate reality.

Furthermore, it was believed that the rational process of the human mind also reflected this cosmic quality. As a consequence, the natural theology of the medieval world resulted from the conviction that a coherent faith should be both accessible to, and comprehended by national processes. As a matter of fact, Christians accept the biblical view that each man is responsible for his neighbours' welfare, and that this obligation must issue in practical attempts to ensure the well-being of all men.

And this must however be rationally justifiable. Thus the child learns that if he obeys the rules as he obeys the parental voice and the teacher's voice, his behaviour gives pleasure and he still derives satisfaction from pleasing those whom he loves and respects. He also learns that infringement of the rules can lead to his exclusion from the group. His rational understanding of the rules still depends on his actually experiencing the consequences of good and bad behaviour.

\section{Conclusion}

In conclusion, this paper has been able to make the point that is being targeted as to how to make moral education programme or campaign a global issue involving leaders, ordinary citizens and students. The ethical or moral assembly should deliberate on the kinds of values that are acceptable to the whole world, using religion in this regard to propagate morality may look reasonable but it must be noted that there is little homogeneity in terms of universal religion and universal morality. The home, the larger society and the school should not renounce their responsibility as regards the moral development of the child. This becomes imperative as asserted by Yoruba proverb which says, 'When the home is unhappy the town appears to be like forest.' All the agencies of education first have to complement each other in making morality an achievable phenomenon in every society of the world and Nigeria in particular. As a matter of fact, the paper has established that education, tradition, and religion functioned as instruments that are used to facilitate the integration of the younger generation into the logic of the present system and bring about conformity to it, thereby making morality an inescapable phenomenon in the societies of the world.

\section{References}

[1] Akinpelu, J.A. (1984). An introduction to philosophy of education. New York: Macmillan Publishers.

[2] Archambault, Reginald (1966). Philosophical analysis and education (ed.). London: Routledge and Kegan Paul.

[3] Coady, C.A.J. (2008). Messy morality: the challenge of politics. New York: Oxford University. 
[4] Immanuel, Kant (1959). The foundations of metaphysics of morals. New York: Bobbs Man. Co. Inc.

[5] Jerome, Brunner (1962). The process of education. Harvard: University Press.

[6] Keniston, Kenneth (1970). Students’ activism, moral development and morality. American Journal of Orthopsychiatry; 40 (4).

[7] Kohlberg, Lawrence (1970). Education for justice. A modern statement of the platonic view. In moral education five lectures. Harvard: University Press.

[8] McConnell, T. (2009). "Conflicting role-related obligations in wit,” In Sandra Shapshay (ed.), Bioethics at the movies. Baltimore: Johns Hopkins University Press.

[9] Peters, R.S. (1974). Reason and habit: the paradox of moral education. Psychology and ethical development. London: George Allen and Unwin Ltd.

[10] Piaget, Jean (1966). The moral judgment of the child. New York: The Free Press.

[11] Schofield, H. (1972). The philosophy of education: An introduction. London: George Allen \& Unwin. 